happen. The subject was pretty well thrashed out last year at Atlantic City. I have seen at least two such sporadic cases in New York City, and others have seen similar cases, where the patient had not been in a leprous country and no source of infection could be traced; these cases are, of course, very rare.

Dr. Schuler, Pittsburg-I only wish to speak of the migration of patients with leprosy. A case came under my care some years ago, of which $i$ was perfectly ignorant at the time, but after looking it over I made up my mind that it was a case of tubcreular leprosy. As soon as I intimated to the lady what was the matter with her she immediately left me and put herself in the hands of some other person, and continued passing from one to another until she landed in Johns Hopkins Hospital, where she died about two years ago. When $I$ was trying to elucidate where she had lived and how she came by the leprosy, she denied ever having been out of the states of Pennsylvania and Ohio, but when she came near to death she told the rest of her history; that she had spent several years in the West Indies, and no doubt from that source she contracted her leprosy. I wanted to speak of the difficulty of getting a truthful history that you ean trace back to a possible origin.

Dr. William F'rICK, Kansas (ity-AIl seem to agree that this is a case of lupus vulgaris, and 1 did hope that the gentlemen would speak of the treatment by $x$-rays. I have had a case which was treated that way and with marked benefit.

I believe I have at present a case of leprosy in Kansas City and it has developed in the United States. The woman was born in Ireland, came very early to the United States, went around from one place to another, including Vicksburg, and for several years has been in Kansas City. She has had the disease for five years. It is principally in the face, with some nodules on the back. I have not been able to corroborate the diagnosis, but the clinical appearance seems to be that of tubercular leprosy.

DR. BuRNsine Fostre, in reply--I have been well aware of the fact that this was a case of lupus vulgaris, but not a typical one; and I had thought, on account of the appearance presented by the scars, that this might possibly be one of those cases which we sometimes see where lupus vulgaris and lupus erythematosus co-existed.

\section{REPORT OF A CASE OF EPIDERMOLYSIS BULLOSA HEREDITARIA.*}

\section{E. SCHMJDT, M.S., M.D.}

CHICAGO.

On account of the comparative infrequency of these cases, but not for any unusual circumstances in connection with it, the case is reported. W. Beatty, in $189 \%$, gave a most complete review of the cases and literature up to that time. Rona, in 1899 , was able to collect but 18 cases in the literature.

As in one case of Dr. Elliot, we find from the history that apparently this affection originated in the patient and was not inherited. In regard to this we know that there must be a starting point, and should there not be any hereditary influence in this case we can not point out why the boy is affected. as the clinical history does not differ from any one of those where we know an hereditary influence is present. Nevertheless, some authorities persist in calling it an hereditary disease.

In my case from its inception the second week after birth the parents believed that traumatism played a rôle in the causation of the bullæ. Nevertheless, after the greatest of care, but especially after the boy commenced to walk, the efflorescences continued to appear.

- Read at the Fifty-second Annual Meeting of the American Medical Association, in the Section on Cutaneous Medicine and Surgery, and approved for publication by the Executive Committee of the Section: W. T. Corlett, L. Duncan Bulkley and W. L. Baum.
The course in all these years has been about the same, neither does it vary as to the time of year.

As has been noticed by Elliot and others, the lesions (i) not leave any pigmentation, as we find so commonly among bullous eruptions. In these cases epidermal cysts, especially noted by Rona, are frequently seen after a bulla has healed, and these in turn quickly disappear and leave but a smooth, glossy, bright-red surface with the creases of the skin absent.

Edwin B.; age 9 years; presented himself for examination April 15, 1899.

Anamnesis.-Both the father and mother denied any hereditary nervous or blood diseases. All that could be ascertained was that their relatives had never been affected by any other than the ordinary diseases. The father is the third in a family of five, and was married at the age of 24 years. The mother is the fourth in a family of seven, and was married at the age of 23 years.

At present (June 1, 1901), they have been married thirteen years, and previously and since then have never been treated for any disease. Both parents regard themselves as perfectly well. although the mother for some years past has irregularities with her menstruations. Beyond this, nothing further can be elicited.

Two healthy boys, the second twenty-three months previous to the one in view, were born. This one was in all respects a normal labor, no forceps or other instrumentation required. Two years later, without any apparent cause, a miscarriage in the beginning of the fourth month occurred. The fourth and last bov was born four years ago. The three other boys seem to be perfectly well. They have had the ordinary diseases of childhood.

The boy under consideration was under 9 years of age; he was never seriously sick, although had measles and whooping-cough some years ago. At time of birth the patient was regarded as normal. No eruption on skin was noticed. Not until about the end of the second week, then commencing in the soles of the feet, just around the heels especially of both feet "water blisters," about the size of a split-pea, made their appearance. These were opened and treated with dusting powder. About the third month, small, regular, from pinhead to size of Lima bean, blisters appeared at irregular intervals on the dorsal surface of the hands and fingers. When he became old enough to walk, which was the usual time, bullæ up to the size of a large thumb-nail began to show themselves around the anterior surface of the knee, around the ankles, apparently especially over tendo Achilles. Beginning at the time, hemp-sized and small vesicles appeared on the dorsal surface. of toes and both feet. Likewise bullæ about the elbow, especially over extensor surfaces, commenced to appear.

Apparently all these became more exaggerated since patient is able to walk and since he is open to traumatism; that is, these blisters came with more frequency, and usually became of quite large size. His mother states that the larger number of these blisters broke usually shortly after their appearance, and remaining contents would dry and in several days only the outer border of a blister would remain. The contents were usually clear, light yellow in color and slightly tenacious. But rarely would the contents become turbid or milky in appearance. If so, the parts became painful and swollen. It is only during the past four years that the contents of some bullæ occasionally become dark, bluish-purple in color. Both the nails of fingers and toes are affected 
and have been so as long as the mother can recall. Occasionally small blisters appeared in the external ears.

I have had the boy under observation for over two years. During this time repeated acute attacks of inguinal and axillary adenitis occurred. After a bulla became infected the corresponding glands would often become painful and greatly swollen almost within twenty-four hours. On physical examination of heart I have occasionally heard a hemic murmur. During this time he has had a bronchitis.

One year ago he complained of severe earache. Dr. Holinger examined him and found a small vesicle at border of membrane. As soon as this disappeared the pain ceased.

During this time he occasionally had some unusual appearances in his case. Several times areas the size of silver 50-cent pieces would become red and itchy,

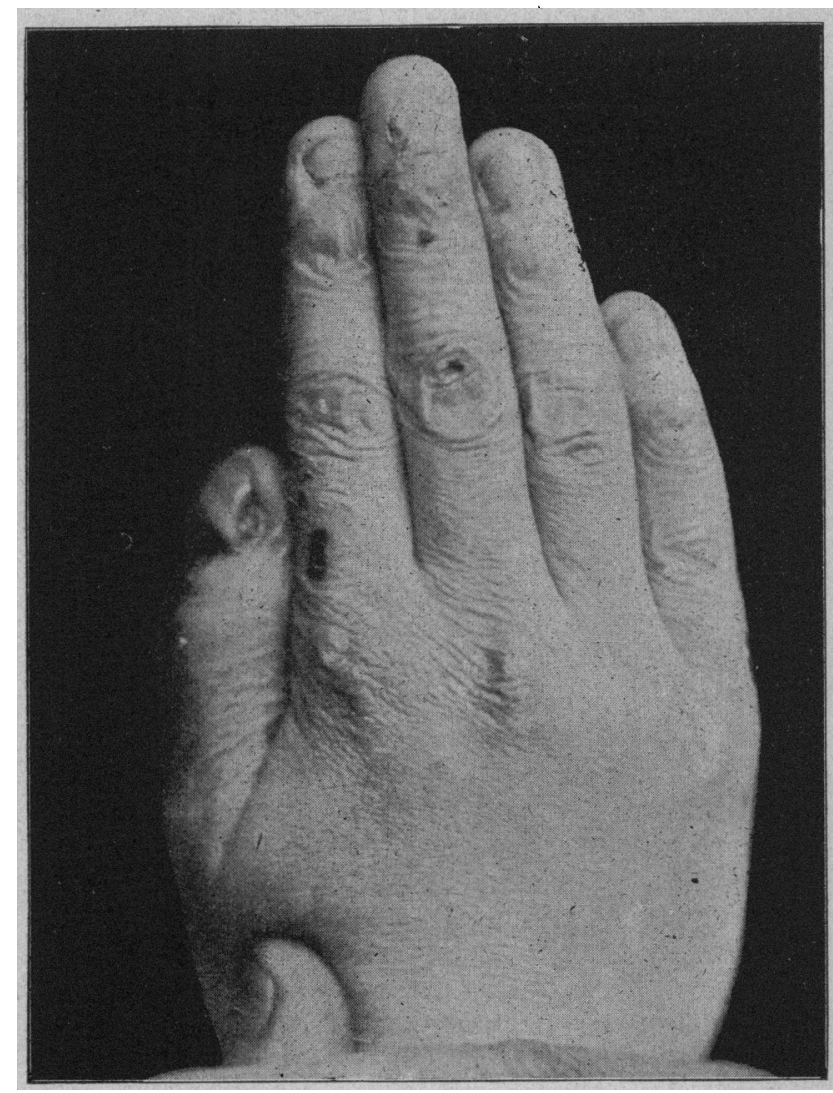

May 10, 1901.

and in a few days scaly. These would be over the lower dorsal vertebræ, exactly in the median line. Besides small vesicles, which would become hemorrhagic, appeared in mucous membrane of tongue and buccal surfaces. Patient would not notice them until he was made aware of their presence.

He can play baseball when hands are in fair condition without causing new blisters to arise. Whenever a new blister does appear he always claims it follows a blow or fall.

His mother states that he has always been peculiar in regard to his diet. He refuses to take almost all vegetables and fruit.

During this entire time I have given patient tonics of all kinds, especially for long periods some form of iron; now for some time cod-liver oil. The blebs, as a rule, have been treated by allowing them to remain closed, or, if very large, by opening and dressing with some inert antiseptic powder or salves according to the needs. The infected and hemorrhagic bullæ were treated antiseptically. The former often required moist dressing in order to give relief.

For four weeks I have had the patient in the Alexian Brothers' Hospital under close observation. During this time the hands and feet were wrapped in inert powder and absorbent cotton. Patient was not allowed out of bed and the hands could not be used; was dressed daily. With every precaution so that the affected parts were well protected and so they could not be used, the bullæ appeared with apparently the same regularity as if this care had not been taken. The acute swelling of the glands was treated with unguentum, Credé, and in no case did suppuration occur.

April 25, 1899: Blood examination showed hemoglobin, 74 per cent.; leucocyte count gave polymorphonuclear, 73 per cent.; large mononuclear, 6 per cent.; small mononuclear, 18.5 per cent.; eosinophile, 2.5 per cent.

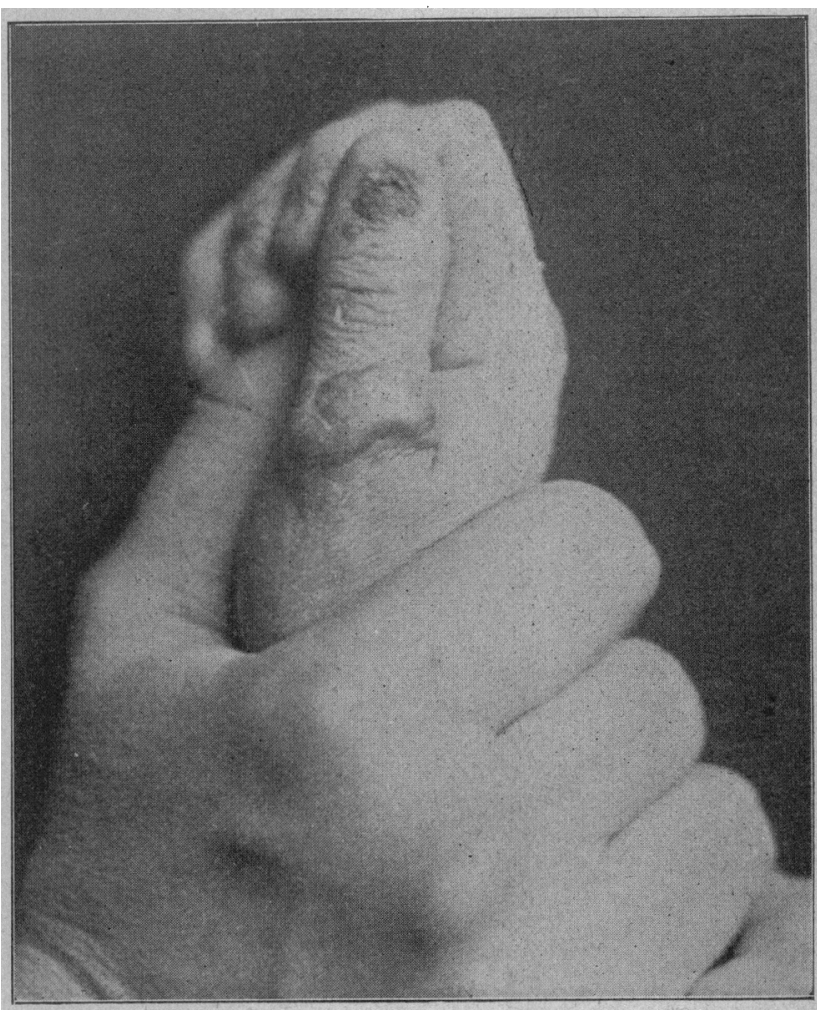

May 15, 1901.

Nov. 10, 1899: A bleb, irregular in shape, about size of a 25-cent piece, completely full, surrounded by a red zone, located on palm of hand. Cleansed and surface made aseptic and sterilized needle attached to Luer syringe was used to aspirate. This turbid thick and grayish colored fluid was transplanted on the ordinary media. Typical growths of the staphylococeus pyogenes albus appeared.

March 6, 1901: Patient returned with a large hemorrhagic bleb at the base of the right thumb and palm of the hand, said to have followed a fall upon his hand. The bleb was opened under aseptic precautions and 5 c.c. of hemorrhagic fluid withdrawn. It was centrifugalized and slides made from the sediment stained with methylene blue and Ehrlich's triple-stain. Cultures were made from the freshly withdrawn fluid and also from the aseptically centrifugalized.

Just below the right patella was another large bulla which was treated in an exactly similar way. The contents were not hemorrhagic, but were perfectly clear.

Four cover-glass stained specimens from sediment of the hemorrhagic fluid showed numerous red blood corpuscles, a few 
leucocytes, two of which were of the eosinophile variety. No growths on any of the media after 72 hours.

March 27, 1901: Since the preceding visit he has had numerous bullæ on the elbows, forearms and hands, and also on toes and about the ankles and knees. Some of those present are hemorrhagie and others filled with clear fluid. One bulla over the right knee was filled with a turbid fluid. This was aseptically treated and transplantations on ordinary media were made. The staphylococcus pyogenes albus was present in all tubes.

Blood taken from ear showed $7 \mathrm{l}$ per cent. of hemoglobin. The leucosyte count showed: Polymorphonuelear, 74 per cent.; large mononuclear, 7 per cent.; small mononuclear, 16 per cent.; eosinophiles, 3 per cent.

April 5, 1901: The condition of patient about the same. Bullæ have come and gone. The contents of several were again

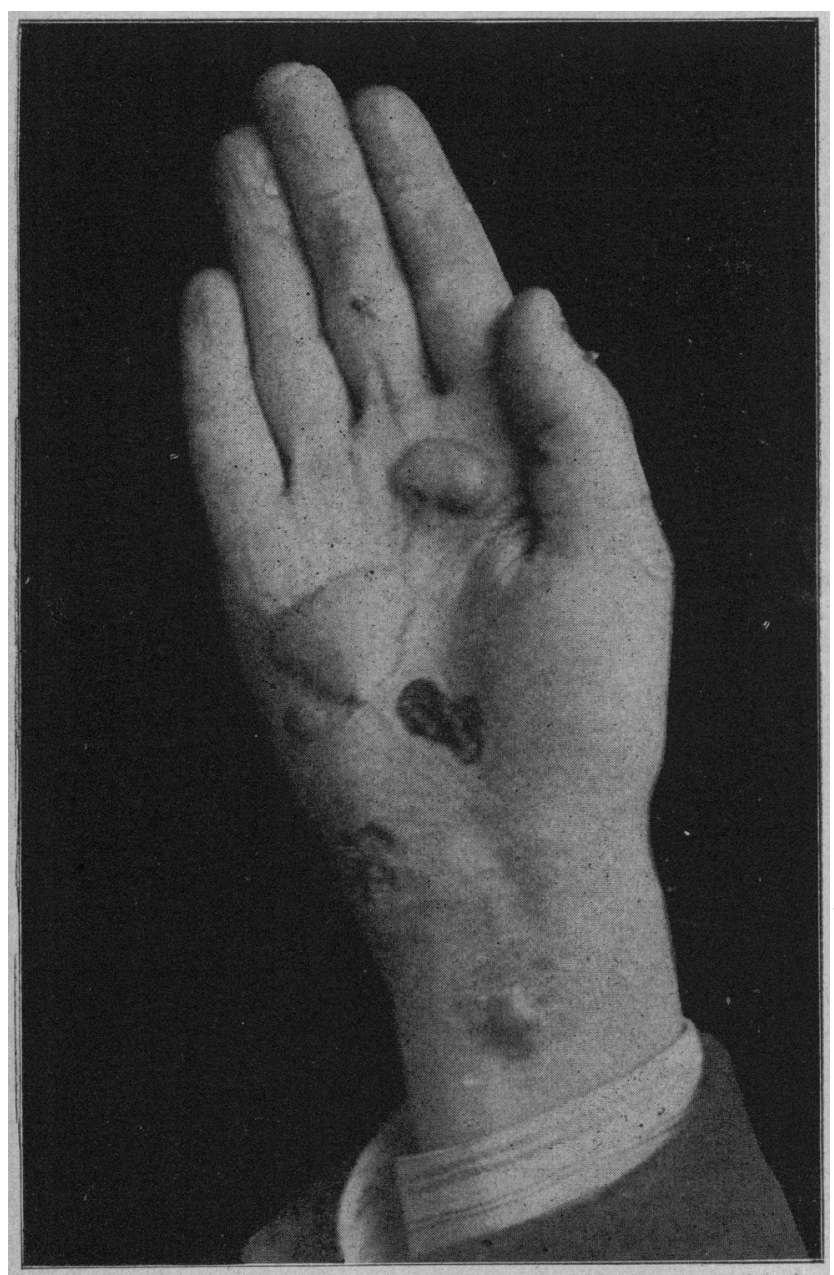

IIay $23,1901$.

examined microscopically. Numerous leucocytes were present and the large number showed no abnormal conditions, but they varied from this to an advanced stage of degeneration. Some were racuolated and had fragmented nuclei. The red cells appeared smaller than those from the general circulation. Besides, transplantations were made, all without showing any growth.

Analysis showed the urine clear, acid, with sp. gr. 1021; no albumin; no sugar: trace of indican; Diazo-reaction nega tive; urea, 1.7 per cent.; microscopic examination was negative.

During the entire time that I have had the patient under observation I have made repeated examinations of blood and contents of the various kinds of blebs, and all with the same findings. I could see no change in the course, that is, no de. crease or increase in the number of blebs during the different stasons of the year. All the functions of the body seemed to be normal. The skin appeared to act freely at all times, and at no time did he complain of excessive sweating of any particular part. Bulla filled with clear fluid, size of a split pea, located about left elbow, involving an area that had never been previously affected, was removed with ethyl chlorid, incising one-eighth of an inch from the efflorescence. Another, considerably larger, filled with hemorrhagic fluid from about the wrist removed under cocain infiltrations. Besides this other parts, including the epidermal eysts, were removed without any anesthesia. All these specimens were treated alike, hardened in weak, then absolute alcohol, mostly all prepared by the celloidin method, but some were mounted in paraffin. The ordinary staining methods were used and Zeiss microscope and lens used for their examination.

Repeated blood examination showed a variation of hemoglobin from 71 to 83 per cent., going up and down in percent-

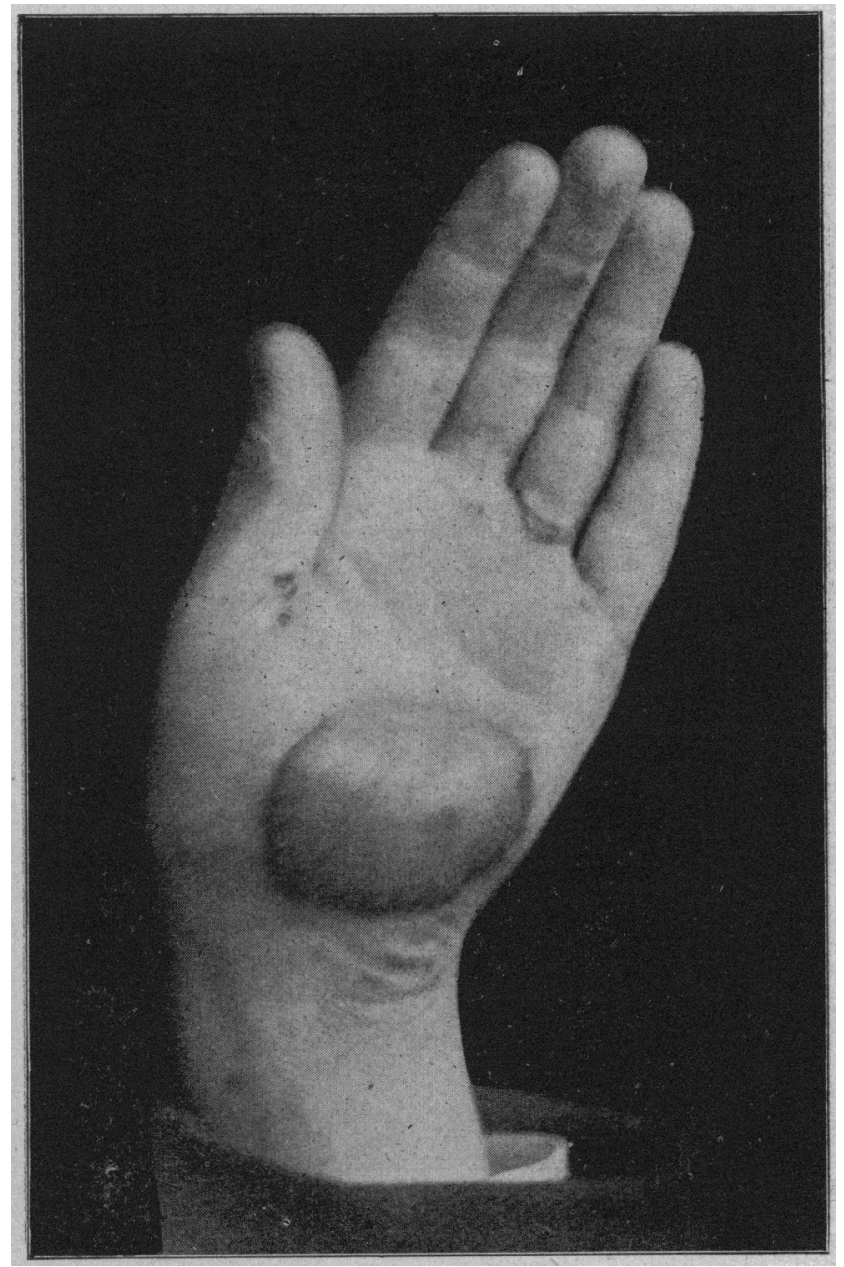

May 23, 1901

age strength. In the leucocyte count we also see variations: Polymorphonuclear, 73 to 75 per cent.; large mononuclear, 5 to 6.5 per cent.; small monuclear, 16 to 18.5 per cent.; eosinophile, 2 to 3 per cent. Continued bacteriological examination of the contents of the clear and also of the hemorrhagic bullæ showed absence of all bacteria. In those that were infected 1 have found the staphylococcus pyogenes albus.

Centrifugalizing the contents of hemorrhagic bullæ, all elements of the blood have been found. The larger number of leucocytes showed degenerative processes. Some were vacuolated and also had fragmented nuelei. The red cells appeared smaller than those of the general circulation.

Urinary examinations were negative to all pathological conditions.

For histological study excisions from healthy to frequently affected parts were examined. 


\section{HISTOPATHOLOGY.}

In the strata spinosum and strata basale in all the specimens examined we find marlied changes. Practically the adjacent cells of these layers show varying cellular destruction. Cells adjoining each other often show great contrast; one may be scarcely involved and the other may be the seat of greatest degeneration. This change involved the cell and its contents, yet no definite relation from below upward could be noticed, nevertheless we see that in the interpapillary changes we find the greatest destruction. In examining a bulla we can see how these affected cells, for the greater part. form the outer wall of the bulla, but few cells remain attached to the papillæ, and these, for the most part, show but little degenerative changes.

At a point where the layers of the bullæ again come together these changes were noticed. In some sections the process apparently stopped suddenly and in others the changes in the cells gradually changed to the normal condition.

'The contents of the bullæ showed differences. In some, fibrinization had occurred-in those of several dav's' standing: also in those that were sanguinous. For the greater part the leucocytes that were present had undergone degenerative changes.

The greater number of blood-vessels showed dilatation, and in addition an infiltration about the same. The character of the latter were such that they were most markedly present in the older lesions and scarcely, or not at all to be noticed in lesions that were excised from areas that had never been previously affected.

In all we find a more or less serous transudate about the immediately affected parts. Whenever this fluid reaches these weakened areas of epithelial cells we get a separation of the same, and is the beginning of a bulla. It would seem as if this disease is non-inflammatory, only becoming so when it has reached the chronic state.

What the primary cause for the degenerative changes in the basal layer and the consecutive flow of serum is we can not explain. It must be some peculiar condition of the skin inherent in these unfortunate individuals.

Status Praesens.-Patient is of average size, although muscular development apparently below average. His general health appears to be good. Skin is somewhat flabby and general color seems to be slightly pale. He exercises the same as his playmates, but he is easily hurt, i. e., blebs arise and give cause for pain, especially if they become infected. In his sehool work he is as far advanced as those of his age. His skin is active, perspires freely, and apparently not unusually from any special area.

Irregularly distributed over the surface of tongue, more towards the median line and extending posteriorly to the circumvallate papillx, from pinhead to one-half hemp-seed sized vesicles, some filled with a clear and others with hemorrhagic fluid. A few of them are so situated that the teeth could not have caused any traumatism. On the buccal mucous membrane on a level where the teeth touch, and opposite decayed teeth, are elongated vesicles filled with hemorrhagic fluid. About these parts a light leukoplakia exists, showing that possibly similar eruptions have preceded it.

On the lower lip, just to the right of the median line, the signs of an old 5-cent piece sized bulla partly extending over the skin.

On the tips of both ears irregular in outline, the border raised and represented by an epithelial layer passing into the normal niveau. Within this outline the skin is of a slightly redder hue. Within ean be seen some parts that have apparently not been affected. These parts as well as all the others are normal to the different sensations.
Exactly over the tenth dorsal spinous process a perfectly round flushed area, silver-dollar in size. It has given him a slight sensation of warmth and itchiness. Over the upper lumbar vertebræ and in the median line an area somewhat smaller in size, color not quite so bright and the surface covered with very minute scales. This has been present some ten days. These have never reached the stage of bullæ, nor have any bullæ ever been noticed on the back.

Thumb-nail of right hand is about to become detached. It is raised, especially at base, and here, too, are transverse striations. The whole is very opaque and slightly movable. On raising a very distorted nail, with rough surface and with no free edge, is to be made out. On the flexor surface over the second phalanx a 10-cent piece sized bulla filled with clear fluid. About the nail and extending over the greater part of the dorsal surface of thumb, is scaly and of $\dot{a}$ dark-red color.

Now, over the metacarpal-phalangeal joints a few small resicles. Interspersed we find pinhead sized white-capped elerations or epidermal cysts, arranged apparently usually in circles, which probably correspond to the outline of some previous existing bullæ.

The entire palm of hand covered with bullous eruptions, several bulla having come together. Contents is dark-purplish in color. About the wrist and extending partly up the extensor surface of forearm a similar appearance to that over the dorsal surface of the hand. Over the extensor surface of the elbow is a bulla one and one-half inches in diameter, comparatively well filled, slightly flabby with clear, semi-fluid liquid.

The nails of the thumb, middle and small finger are similarly affected as on the right side, except that a whitlow exists about the index finger-nail, it having followed a bulla. The palm of hand and dorsum as well as wrists and elbow showed a few bullæ, epidermal cysts and also red and scaly patches.

Nails of toes of right foot are all irregular, small, surface rough and apparently poorly nourished. Over dorsal surfaces of all the toes a reddish scaly condition and a few small vesicles present; similarly on the toes of left side. Never any bullæ on soles of feet, only occasionally on the dorsal surfaces, consequently only normal skin. About the malleoli and over the lower part of the tendo Achilles we find a few blebs and remains of old ones. No signs over tibix of any previous affections, but at present over both knee caps, palm-sized, flabby bullæ. About these scaly and discolored skin.

The hands show no signs of any cyanosis or edema. The shape appears to be normal, except when bullæ are present. The palms and dorsal creases are present when not temporarily affected by bulla. Especially on the extensor surfaces of the extremities where bullous eruptions have frequently existed we find the skin glossy, tense, and the normal striæ of the skin lost or all the appearances of atrophy present. In these areas we find these epidermic cysts. These apparently go and come without leaving any permanent macroscopic changes.

I have attempted with heat, chemicals, and mechanical means to cause bullæ, but without avail. A slight redness would appear, but only of passing moment.

Of late there seems to be a tendency among some authorities, among whom we find Hallopeau, to bring all these cases under one class, yet to recognize different varieties. All varieties have some things in common. We find, 1, that shortly after birth or usually at latest in early youth. there is a tendency for traumatic bullous eruptions; 2 , that similar areas are affected; 3 , that it is hereditary; 4 , that the general health is intact; 5 , that the course is chronic and remains uninfluenced by therapy.

Now, the dystrophic form of Hallopeau includes the case which I report. Because, in addition. it has consecutive atrophy of the skin, epidermal cysts and distortion of the nails. Those cases that belong to the simple variety can not have any one of these chanres present.

That these types exist we must admit. Certainly t's clinical appearances are very marked. Without doubt 
these differences are so great that we must admit of tre possibility of rarieties. But it is asked: Why make such classifications? Have we not various diseases in which one or more clinical srmptoms are absent and yet call one and all the same? No two cases of different types in the same family have yet been reported. This would almost certainly be a connecting link between the two and to some extent clear the question.

I think that we are still in doubt, and that for the present it will be best not to classify all under one and the same disease.

\section{LITERATLEE.}

S. Rona: Archiv für Dermatologic und Syphilis, 1899.

W. Beatty: British Jourual of Dermatology. 1892.

G. Elliot: New York Iredical Journal, 1900.

Goldscheider: Monatshefte für Practische Dermatologie, 1882.

Bettmann: Archiv für Dermatologie und Syphilis, 1901.

Hallopeau: Traité pratique de dermatologie, 1900.

L. Phillipson: Giornale italiano delle malattie veneree e della peile, 1900 .

G. Elliot: Journal Cutaneous ancl Gunito-Crinary Diseases, 1895 L. Torök: Festschrift zum Jubiłäum Schrimmer's, 189 \%

Blumer: Archiv fiir Dermatologie und syphilis, 1892.

Herzfeld : Jerliner Klinische Wochens.hrift, 1893.

17

DISCL'SSION.

Dr. F. H. Mon'ronery, Chicago-l am only sorry Dr. Schmidt can not show the case here. Those of us who have been fortunate enough to see this case have no doubt regard. ing the correctness of Ir. Schmidt's diagnosis.

Dr. M. L. Heidrsasfeld. Cincinnati-C'The feature which has impressed me most strongly in Dr. Schmidt's interesting paper, is the low percentage of eosinophilia, less than 2 per cent, if I remember rightly. This corresponds to the recent investigations of Bettmann of Heidelberg, who has found an exceed. ingly low percentage of cosinophilia in epidermolysis bullosa, which is in direct contrast with nearly all other forms of bullous eruption. and what is most interesting, is also in direct contrast with the investigations of nearly all other writers on epidermolysis bullosa, notably with Columbini, who claims an eosinophilia of 14 per cent.

The nature of the bullæ in this disease is also a matter of peculiar interest. It has been noted that sinapisms, in the torm of mustard plasters, Spanish-fiy, ete., when applied over the predisposed pathological areas, are unattended by resication or even redness, while on the other hand, these symp toms are promptly induced orer normal tissues elsewhere, which from the very nature of the disease, is the converse of the anticipated. Subcutaneous injection of normal salt solution, over the pathological areas, has been followed by the formation of bulla which have tise same appearance and pur. sue the same course, as those of spontaneous nature. From this, the deduction has been drawn, that the essential factor underlying this peculiar condition, is an undue relaxation of the areolar connective tissue. which readily permits and fia vorably prolongs an exudation.

Dr. Louis E. Schmint, in reply-This case has been differ ent from the cases reported in the literature. I know in regard to some of the findings, especially as far as being able to raise bullæ by artificial means and in hlood examinations, they differ very markedly fron some of the authorities. 'J'he microscopic findings are practically the same as those of Elliot.

New York State Insane.-Inequalities in county statistics of the insane are pointed out by the lay press without assigning any causes for the discrepancies. Thus Ontario county, with 49,000 inhabitants, has 185 insane, while Clinton, with 47,000 , has but 83 . Rensselaer, with 121,000 , has 527 insane. while Oneida, with 133,000 , has but 438 . [1]ster, with 88,000 , has 265 insane, while Duchess, with 81,000 , has but 360 , and St. Lawrence, with 89,000 , has 209 . Orange county, with 103,000, has 357 insane, while Westchester, with practically the same population as Orange, has 500 insane.

\section{IRCTRACTED INFLUEAZAL PNELMONIA IN INFANCY.*}

FRANK X. WALLS, M.D.

IROFLSG OF CLIACAL PEDITRICS, NORTHWFSTER CXIVERITY.

\section{CHICAGO.}

While no period of life is exempt from influenza, it has been observed, during the pandemics of grip that have encircled the world, that infants are in a high degree immune from this scourge. During the recent epidemic of December and January, 1900 and 1901. J. had under my observation, at the one time and in the same institution, four infants suffering from protracted pneumonia of influenzal origin, which, I trust, are of sufficient interest to present their histories and exhibit some pathologic specimens.

It is not my wish to convey the impression that grip iin infants usually runs such a protracted course as the cases I present. During this period of life, grip is as protean in all its characteristics as in other life epochs. None the less the simultaneous occurrence of four cases in an institution that shelters sixty to seventy-five babies argues for the great frequency of severe and protracted forms, if infants be aflicted with influenza.

Etiology.-These four infants were fed exclusively on artificial food at the time they contracted the grip, and two of them had been nourished in this manner since birth. This is in accord with the observation that nursing children are almost absolutely immune, even though their mothers be seriously stricken with the grip. This immunity is explained by assuming that a potent antitoxin is eliminated in the maternal milk. Infants artificially fed are more susceptible than babies at their mother's breast, but are less susceptible than adults. Comby estimated that the morbidity among children in Paris during the pandemic of 1889 and 1890 , was 40 per cent., and among adults was 60 per cent. We may state that the influenzal sick-rate, which is nil in young infants, progresses and regularly increases up to adult life. The youngest child that Comby reports with the grip was $1 \%$ days old, and he saw three nurslings contract the grip while nursing their sick mothers. This latter observation is quite exceptional. Relapses among children are not rare, but second attacks, during the same epidemic, are exceptional. The contagiousness of infiuenza is very great, and. particularly in institutions caring for a number of children. the afflicted infants should be isolated.

Symptomatology.-The onset, in these cases of protracted grip-pneumonia, was rather precipitate, and presented the clinic picture of a more or less severe gastrointestinal infection, to which, in a few days, symptoms of involvement of the respiratory tract were added. Convulsions were not present. neither were there any pronounced nervous symptoms, such as stupor, chill, etc., though some irritability or restlessness was early present.

Usually the first symptoms observed would be that the child refused its food, or, if it had taken some, would romit. It would be cross and fretful, would have a high fever, the breathing would become fast, then hurried and jerky. Cough, at first short and occupying a single expiration, would increase in intensity until it might be paroxrsmal and continuous as in pertussis. The bowels were usually constipated and a considerable

* Read at the Fifty-second Annual Meeting of the American Medical Association. in the Section on Diseases of Children, and approved for publication by the Expcutive Conmittee of the Section: II. E. Tn!ey. Fdwin Rosenthal and Samuel W. Kolley 